\title{
Economic Mechanisms for Managing Food Security in the System "Production-Consumption-Import"
}

\author{
Aleksey Rogachev ${ }^{1}$, Tamara Mazaeva ${ }^{1} \&$ Ekaterina Egorova ${ }^{1}$ \\ ${ }^{1}$ Volgograd State Agrarian University, Volgograd, Russia \\ Correspondence: Aleksey Rogachev, Volgograd State Agrarian University, Ap. 109, 6, Sovetskaya str., \\ Volgograd, 400066, Russia. Tel: 79-27-257-9342. E-mail: rafr@mail.ru
}

Received: June 1, 2015 Accepted: June 22, 2015 Online Published: July 15, 2015

doi:10.5539/ass.v11n20p185

URL: http://dx.doi.org/10.5539/ass.v11n20p185

\begin{abstract}
Green revolution almost spent its resources, and scientists haven't found the way for the quick increase of potential capabilities of newly bred sorts of grain crops, grain legumes, and cereal crops, of potato, sugar beet, vegetables, and feed crops. Due to impossibility of use of ecological tools, there is a necessity for the search for new ways of providing food security. In this research, economic mechanisms of managing food security in the system "production-consumption-import" are developed. The authors analyze the notion and meaning of economic mechanism, determine the current state of food security of modern Russia in the system "production-consumption-import" in comparison with other countries, and determine problems and perspectives of its increase. As a result of conducted analysis, the authors come to conclusion that current food situation in Russia is characterized with features of chronic lack of food and incapability or lack of wish of their authorities to solve this problem. Socio-economic state of agriculture does not ensure the economic accessibility of food products for all groups of population. As the key economic mechanisms for managing food security, this research offers the formation of growth poles, or economic cores, and creation of agricultural clusters.
\end{abstract}

Keywords: food security, economic mechanism, manufacture of good products, consumption, consumption norms, food products import

\section{Introduction}

In the 21 st century, the food problem is, without any doubt, the most important, sharp, and topical for all humanity. Despite large progress in the development of agriculture, of river and sea fishing, and food and processing industry which provided humanity with higher level of food products consumption, the problem of food is not fully solved by humanity.

According to the UN, more than 1 billion people on the Earth starve constantly, 13-18 million people die annually of hunger and starvation, and 35 people die every 24 hours as a result of direct or indirect starvation. As to the quantity of casualties, no other catastrophe on the Earth can be compared to starvation. Only over 1983-1985, more people died in the world of starvation than during World Wars I and II combined (Garthwaite et al., 2015).

Uncertainty of food problem can be explained by a range of causes. Firstly, by high rates of population growth on the Earth, which far exceed the global rates of growth of food volumes. While at the beginning of new era, there were around 200-250 million people on the planet, and the first billion was reached 2000 years later, the second billion was reached 100 years later, and the fifth -20 years later. At present, annual growth of population is estimated to be 90 million people, and, according to the UN data, in 30 years, the population of the planet will reach 8.5 billion, and in 100 years -14.4 billion people. On the one hand, this aggravates the food problem, and, on the other hand, strengthens serious load on the natural environment, the main components of which are means of production and subjects of labor for agrarian sector of economy (Jacknowitz et al., 2015).

Secondly, reduction of area of cultivable land and fresh water for irrigated agriculture. During the period of agricultural activity - around 10,000 years -2 billion hectares of land was lost. During recent 300 years, agriculture lost 700 million hectares, with average annual rate of loss constituting 2.5 million hectares; and during recent 50 years, 300 million hectares was lost, with average annual rate of loss of 6 million hectares. 
Modern real losses of productive lands exceed by 30 times the average historic values and by 2.5 times - the volumes of losses during recent 300 years (He, 2015).

Green revolution almost spent its resources, and scientists haven't found the way for quick increase of potential possibilities of newly bred sorts of grain crops, grain legumes, and cereal crops, potato, sugar beet, vegetables, and feed crops. Due to impossibility for use of ecological tools, there is a necessity for the search for new ways of providing food security. In this research, economic mechanisms of managing food security in the system "production-consumption-import" are developed.

\section{Subject}

The subject of the research is economic mechanisms of managing food security in the system "production-consumption-import" by the example of modern Russian economy.

\section{Materials and Methods}

Food security is a complex self-organizing system, the mechanism of functioning and development of which hasn't yet received theoretical substantiation. The mechanism of the system of food security is one of its sub-systems, a kind of systemic organization of the system.

Mechanism has one goal - to organize something. Achieving this goal is implementation of the mechanism. Consequently, the sense of mechanism is its goal plus achievement of the goal (sum of necessary regularities and qualities). From the substantial point of view, the system of food security should be viewed as a unity of three components - organizational structure, strategy, and organizational \& economic mechanism.

The main substantial (structural) elements of any organizational and economic mechanism are economic agents and relation between them. Economic agents (enterprises, establishments, husbandries) are the subjects of the system of food security.

Implementation of the mechanism of functioning and development of the system of food security is aimed at provision of coordinated cooperation of economic agents, in the process of which the goal of the system is achieved - constant satisfaction of population's need for food products. The study of the mechanism of food security from the positions of systemic approach allows presenting it as an aggregate of:

- Organizational structures, forms, and methods of management, as well as legal norms which help to realize the existing economic laws and ensure the process of reproduction in agroindustrial sphere;

- Interconnected elements in the form of economic subjects and their interrelations;

- Interconnected informational \& analytical centers which perform monitoring, evaluation, and development of managerial decisions for provision of food security at macro-, meso-, and micro-levels of agroindustrial system.

The main elements of the mechanism of functioning and development of this system are:

a) state regulation of economy;

b) pricing mechanism;

c) financial and credit mechanism;

d) tax system;

e) economic and commercial accounting;

f) organization of production, labor, and management at agroindustrial complex enterprises;

g) agro-marketing.

We offer the following definition: "Food security mechanism is a self-organizing system of economic agents (enterprises, establishments, households) with peculiar economic mechanisms and public institutes, typical for the whole system, which regulate the activities of economic agents".

Organizational and economic mechanism is a mechanism of adaptation of the food security system to the changes of external environment. There are substantial differences between the processes of current financing and development of the food security system. This is the reason for usage of different approaches for managing these processes and for integration of managing the both processes within single system.

Mechanism of functioning determines the order of interaction between economic agents and government bodies which conduct the management of the food security system; during this process, organizational \& managerial, production \& technological, and financial \& economic interrelations of the system subjects are formed. 
The subjects of the food security system enter organizational \& managerial interrelations which include development and implementation of agrarian policy, determination of rational list of members of technological chain "production-distribution-redistribution-consumption of agricultural products", development of regulatory act which regulate the activities of economic agents, and setting the sizes and order of formation and use of food reserve.

Production \& technological interrelations affect the production cycle and are manifested through division of labor and exchange of the results of activities of reproduction process members of agrofood sphere.

Financial \& economic interrelations are manifested in the process of exchanging the results of production in industry and agriculture, distribution of profit from joint activities of the members of reproduction process in agroindustrial complex, and use of loan assets for the development of economic subjects in agroindustrial complex.

The mechanism of development of the system of food security is the totality of the elements of this system which develop and implement targeted actions and procedures for changing its parameters, structure, and features in response to the influence of external and internal factors of environment for the purpose of increasing the functioning and development of the system. On the basis of this definition, it is possible to conclude that the mechanism of development is an adaptive mechanism which allows taking into account the influence of external environment factors.

The mechanism of development of food security system determines the range of requirements and peculiarities of formation of its structures (targeted, functional, and organizational), the performance of which requires:

-formulating the list of requirements to system's goals;

-determining the model of goals structuring;

-determining parameters of targeted function;

-performing quantitative and qualitative evaluation of goals;

-determining the variety of development goals in the variety of goals of food security sub-system;

-determining the peculiarities of formation and implementation of system development goals;

-determining the goal implementing of managing sub-system and management object;

-determining the peculiarities of goal-setting system;

-determining the list and sequence of performance of general functions of management;

-viewing the content of main stages of formation of organizational \& economic mechanism of development of food security system.

Modern food situation of Russia can be characterized by chronic loss of food and incapability or lack of her authorities' wish to solve this problem. It has been 21 years since the beginning of agrarian reforms, and socio-economic position of agriculture and modern state of economic accessibility of food products for all groups of population do not give any reasons for optimism. However, estimates of the reduction of food production are different, but, whatever standards are used for evaluation, the scales of the reduction are huge.

At present, 50 regions of the Russian Federation with population of more than 87 million are beyond the criteria of food security; as to milk and dairy products -28 regions with 52.8 million people. At that, in 50 regions with population of 78 million people, the consumption of meat products per capita is lower than the average one in Russia; the consumption of milk per capita is lower than the average one in Russia in 48 regions.

It should be noted that the number of regions with dominating import of food is growing dynamically, and this significantly aggravates the situation with food security of the country and strengthens its import dependence. Consumption of main food products in developed countries of the world is characterized by the following data.

As is seen from Table 1, only the people of Japan consume less meat than the Russians. At that, it should be noted that the Japanese consume $55.3 \mathrm{~kg}$ of fish and sea products per year, while the Russians - only $9.3 \mathrm{~kg}$.

In the internal market of food products, there is a quick growth of retail prices and the share of large trading chains which set high trading margins, which cannot but influence the economic accessibility of food especially, for lowly-paid category of population. Trading margins for food products in Russia constitute $25-40 \%$, while in Canada, China, and Belarus they are regulated by law and do not exceed $12 \%$, and trading margins for socially important products do not exceed $8 \%$. 
Table 1. Consumption of main food products in developed countries, kg per capita, 2014 (Maitra \& Rao, 2015)

\begin{tabular}{cccccc}
\hline Product & Russia & Germany & USA & France & Japan \\
\hline Meat and meat products & 46 & 86 & 115 & 91 & 45 \\
Milk and dairy products & 229 & 435 & 312 & 426 & 94 \\
Butter & 3.5 & 7.1 & 2.0 & 8.6 & 0.8 \\
Eggs & 210 & 224 & 233 & 282 & 320 \\
Fish & 9.3 & 14.1 & 10.5 & 20.0 & 55.3 \\
Sugar & 33 & 33 & 30 & 35 & 21 \\
Oil & 8.4 & 17.0 & 24.6 & 18.8 & 14.6 \\
Potato & 130 & 75 & 64 & 84 & 102 \\
Vegetables and gourds & 79 & 87 & 111 & 130 & 123 \\
Fruits and berries & 33 & 129 & 101 & 84 & 60 \\
Bread products & 118 & 77 & 103 & 82 & 118 \\
\hline
\end{tabular}

There is ongoing process of property stratification of society. In the population groups with the least resources per capita, as compared to group with the most resources, the consumption of meat and meat products is lower by 2.5 times; milk and dairy products - by 2.1 times; eggs - by 2.7 times; vegetables and fish products - by 2.2 times; fruits and berries - by 3.9 times. While in 1990, the average daily ration in Russia was 3,420 calories, over the recent years it reduced to 2,500-2,700 calories, with Food and Agricultural Organization's recommended level of 3,000 calories per day. At that, there has been the reduction of the most valuable in the energy aspect products - meat and dairy products, fish and eggs.

Food independence of the RF is the state of the country's economy, at which the cease of import of food products into the RF does not lead to food crisis, and annual production of the most important food products constitutes at least $80 \%$ of the annual need of population for them, according to physiological norms of nutrition.

Physical accessibility of food is the availability of food, guaranteed by the state, on the whole territory of the country and at any moment in volumes and assortments which satisfy and correspond to payable demand of population.

Economic accessibility of food is the level of buying capacity of population with existing structure of consumption, pricing system, and level of incomes, social benefits and subsidies which provides the possibility for the population's purchasing the main types of food according to the recommended norms of nutrition.

The doctrine of food security of the Russian federation determines threshold values of food security. Share of the Russian agricultural raw products and food in the total volume of sales in the domestic market should constitute not less than: corn and potato $-95 \%$; sugar $-80 \%$; oil $-80 \%$; meat and meat products $-85 \%$; milk and dairy products in equivalent of milk $-90 \%$; fish and fish products - $80 \%$. At that, the indicators of the Food and Agricultural Organization for the allowable share of import of food products of $17 \%$ were taken into account (Popkova \& Tinyakova, 2013a).

For example, the USA and EU proceed from the necessity for providing $100 \%$ of food security. Even Japan, where the area of tilled soil per capita is less than in Russia, provides her population with own rice by $100 \%$, and with other food products - by $45 \%$, despite the fact that cost of rice production is 7 times higher than in other rice-producing countries (Popkova \& Tinyakova, 2013b).

The goals and tasks of providing food security include the following:

Food independence in parameters, set by the Doctrine of food security of the RF;

Sustainable development of rural areas, creation of favorable and attractive conditions for rural population;

Modernization and transition to innovational model of agroindustrial complex development;

Reproduction and increase of the use of land and other natural resources;

Development of small business patterns and cooperation, as an important factors of economic viability of Agricultural manufacturers and provision of their access to agrofood market. 
Russia cannot hide from the issue of providing the population with own food. However, this path will be a long one, and expenses will be huge. In 2011, the total investments into agricultural economy and social sphere constituted a pathetic sum of RUB 160 billion. The investments are huge, and the rates are growing annually. Still, I comparison with leading countries of the world, these investments are very small (Mazaeva \& Rogachev, 2012).

Thus, as to the cost of food, our budget investments constitute $5.4 \%$, while in the USA - $18 \%$, Norway - $72 \%$, Japan $-58 \%$, the EU $-37 \%$, and Canada $-21 \%$. The society has to understand that there is no independent prosperous democratic state of the decent level of the 21 st century without own highly developed agriculture and food industry.

\section{Results}

The indicators of socio-economic development of agriculture are those which express quantitatively its sense, possess a high level of sensitivity and variability, and are capable of warning the state and market subjects of possible dangers in the sphere of food provision (Popkova et al., 2013):

- $\quad$ volume of gross output of agriculture and food, per capita;

- $\quad$ gross corn yield per capita;

- $\quad$ financial \& economic situation;

- $\quad$ share of investments into main funds;

- $\quad$ share of imported food in the total volume of food resources.

In order to give adequate responses to modern challenges, Russia has to start developing additional measures for quick recovery of domestic agroindustrial production and to introduce corresponding changes into government's plans for short-term and long-term. Primarily, this refers to food import substitution - especially, cattle breeding products.

We offer two approaches for solving the food problem under the conditions of counter-sanctions. Firstly, cluster approach. Cluster is a key tool for managing territorial agroindustrial policy. In Russia, this theory is not thoroughly developed. In practice, this is manifested in insufficient companies' integration, weak use of modern production technologies, and ineffective antimonopoly policy.

Secondly, the formation of growth poles, or economic cores, is of great interest. Implementation of the strategy on the basis of "cores" requires realization of the following measures (Mazaeva, 2012):

- change of paradigm of managing agroindustrial complex in the direction of clear structuring of elements of economic mechanism;

- increase of areas of regulation and participation of regional budgets in the capitals of integrated companies;

- increasing the status of regional agroindustrial policy, etc.

The main form of state support for agroindustrial complex are federal and regional targeted programs which stimulate commodity production of the types of products which are necessary for saturation of food market and which are competitive enough.

The top-priority direction of agroindustrial complex development is wide usage of progressive technical means and new technologies in crop production, cattle breeding, and processing industry. It may be the means for large growth of food production.

In all developed countries, the state, with the help of various economic and financial actions and means (including the system of subsidies and compensations, relieving taxation or tax remissions, reduction of tariffs for resources used in agriculture, system of crediting and insurance with budget compensations, etc.) conducts constant support for agriculture. This allows not only improving the food provision of the population but exporting large volumes of agricultural production and food products.

The development of production potential of agroindustrial complex requires the national program of stimulation of food export with the usage of global experience. At present, the state provides minimal support for export-oriented manufacturers, while such forms as export subsidizing, crediting and credit insurance, and informational \& consultative services are used by all states and do not contradict the rule of the WTO (Rogachev et al., 2014). 
Development of export productions will allow attracting investors in the spheres of agroindustrial complex which now are considered to be unattractive for investments. Investments in the stimulation of agroindustrial export are paid off quicker than in the spheres which are oriented primarily at the internal market.

For reasonable selection of the strategy of actions for preventing or neutralizing the emerging threats, it is necessary to conduct expert surveys for the purpose of determination of the level of their influence on the consumer market and evaluation of probability of their emergence.

On the whole, despite the influence of negative factors, most of exports evaluate the perspectives of growth of main spheres of agroindustrial complex in mid-term optimistically - under the condition of certain efforts, which, undoubtedly, will influence the inflow of investments into this sphere of economy.

Development of the Russian production is a main path for reducing inflation rates, growth of income, and rationalization of the consumption structure of the Russian population. The development of clever protectionist policy for protecting the Russian internal market with the use of mechanisms of custom duties is urgently required.

While solving the problem of necessary volume of subsidies for agricultural production, one should proceed from normative cost and profitability of product, the size of which will allow enterprises providing the necessary average annual rates of growth of agricultural production and implementing high-tech equipment for manufacture of competitive agrarian products.

The state strategy of regulation of particular spheres of agroindustrial complex, on the basis of generalization of experience of competitive struggle, should be determined in view of the stage of the sphere's economic cycle. The most important indicators which allow identifying certain stages of economic cycle (growth, fall, decline) of particular spheres of agroindustrial complex and enterprises' capability to invest assets into new equipment are: volume of corporate profit of enterprise before taxes and volume of corporate profit after taxes and undistributed profits, i.e., company's profit after payments and distribution of dividends.

Monitoring of the first two indicators should be performed every quarter. Reduction of the volume of corporate profit of the sphere after taxes during three quarters is an indicator which allows forecasting the reduction of rates of economic growth or start of decline in this sphere.

Positive expectations of the growth of agroindustrial sector of economy are caused by effective government decisions, including the ones as to export and import of food. There's a great concern with the market being influenced by large volumes of imported products which influence food market, thus increasing the insecurity of the Russian manufacturers.

\section{Discussion}

The conducted analysis allows stating the necessity for provision of absolute importance of internal national interests over external ones and reduction of internal food market's dependence on the changes of global situation. At that, limited protectionism is used not for artificially preserved relative competitiveness but for creation of conditions for development of agroindustrial complex of the country in view of market laws and provision of accessibility of food for all population groups. This requires the state regulation of import of agricultural products, raw materials, and food, which is conducted primarily by economic measures.

While viewing the question of joining the WTO, it is necessary to protect Russia's right for economically reasoned protectionism and state support for agriculture which primarily includes preservation of the level of budget subsidies and other measures of state support, required for stabilization and development of agroindustrial complex, preservation of required level of internal market protection, right for subsidizing the export of agricultural products, raw materials and food for increasing the competitiveness of domestic production in the global market. Support for the Russian manufacturers in the internal market should include the following measures:

- monitoring of the situation of the global and Russian food market and timely reconsidering the rates of import customs duties;

- differentiation of rates of import customs duties on agricultural products, raw materials, and food, depending on the level of their processing;

- expansion of use of tariff quotas for certain types of imported goods; activization of investigation of damage to domestic manufacturers of agroindustrial complex, and the use of protective, anti-dumping, and compensational measures, of quotas and licensing of import of certain types of agricultural production, raw materials, and food; 
- development of infrastructure of food market and increase of its accessibility for all manufacturers of agrofood sphere;

- prevention of setting transregional trading barriers, including during purchase of agricultural raw materials and food for budget organizations and establishments, which will improve the physical accessibility of food for population in various regions;

- development of the system of targeted aid (depending on the level of expendable income of family) for the most destitute population groups and organization of full and complex analysis of evaluation of the food security state - "food monitoring" of the population;

- introducing changes and revisions to current regulatory acts for the purpose of creation of single state body for control of the quality and security of food products, through uniting departments which deal with development of standards with departments responsible for their observation;

- stimulating transition from manufacture of "impersonal" food to the issue of domestic food products under trademarks which will increase quality and competitiveness of products of the Russian manufacturers.

Development and implementation of effective strategy for development of food market, formation of sustainable economic ties between Russian manufacturers and consumers of agricultural products, as well as improvement of the system of products movement towards consumers will allow providing the food security of the Russian Federation and implementing national interests of Russia in the globalizing world.

\section{Conclusion}

Managing the processes of provision of food security within the process of increasing the level of economic security of agroindustrial complex at all levels requires the policy aimed at overcoming internal and external threats which should include the following measures:

- monitoring of factors determining threats to food security, which will allow forecasting crisis phenomena in agroindustrial complex and determining their influence on food security of the country. In our opinion, this will require changing the functions of the Federal State Statistics Service in the sphere of collection, depth and forms of coverage of statistical observation objects;

- $\quad$ in view of specifics and peculiarity of geographical position of the subjects of the RF, their zonality, and specialization, leading R\&D establishments of Russia should create a system of criteria and parameters (threshold values) of food security. This will allow evaluating the self-sufficiency of the Federation's subject and implementing complex of measures, aimed at preventing or overcoming the threats to food security of Russia;

- creation of conditions for easy-term loans for economic business subjects of agroindustrial complex, their interest in smooth system of interrelations "production-processing-final products sale";

- development of mechanism for elimination of price disparity, which, in our opinion, is the biggest threat to provision of food and economic security of agroindustrial complex;

- development of rural infrastructure and increase of the educational level, which will allow forming effective HR potential;

- $\quad$ achievement of integration of science into production - as practice shows, new species of animals and plants, and new types of equipment are still not available for agricultural manufacturers;

- changing the order of investing into production and of taxation of business subjects of agroindustrial complex.

Thus, economic security of agroindustrial complex and food security of the Russian Federation should be based on effective economy in the technological chain "manufacturer of means of production for agroindustrial complex - production of agricultural products - processing of agricultural products - final products sales".

\section{References}

Garthwaite, K. A., Collins, P. J., \& Bambra, C. (2015). Food for thought: An ethnographic study of negotiating ill health and food insecurity in a UK foodbank. Social Science and Medicine, 132(1), 38-44. http://dx.doi.org/10.1016/j.socscimed.2015.03.019

He, J. (2015). Chinese public policy on fisheries subsidies: Reconciling trade, environmental and food security stakes. Marine Policy, 56(1), 106-116. http://dx.doi.org/10.1016/j.marpol.2014.12.021

Jacknowitz, A., Morrissey, T., \& Brannegan, A. (2015). Food insecurity across the first five years: Triggers of 
onset and exit. Children and Youth Services Review, 53(1), 24-33. http://dx.doi.org/10.1016/j.childyouth. 2015.03.012

Maitra, C., \& Rao, D. S. P. (2015). Poverty-Food Security Nexus: Evidence from a Survey of Urban Slum Dwellers in Kolkata. Source of the World Development, 72(1), 308-325. http://dx.doi.org/10.1016/j. worlddev.2015.03.006

Mazaeva, T. I. (2012). Modern state of cattle breeding in view of food security. University Bulletin (State University of Management), 1(1), 59-63.

Mazaeva, T. I., \& Rogachev, A. F. (2012). Mathematical modeling and analysis of the processes of implementing technological innovations in view of economic security. Economy and entrepreneurship, 5(28), 296-298.

Popkova, E. G., \& Tinyakova, V. I. (2013a). New Quality of Economic Growth at the Present Stage of Development of the World Economy. World Applied Sciences Journal, 5(1), 617-622.

Popkova, E. G., \& Tinyakova, V. I. (2013b). Drivers and Contradictions of Formation of New Quality of Economic Growth. Middle-East Journal of Scientific Research, 11(1), 1635-1640.

Popkova, E. G., Morkovina, S. S., Patsyuk, E. V., Panyavina, E. A., \& Popov, E. V. (2013). Marketing Strategy of Overcoming of Lag in Development of Economic Systems. World Applied Sciences Journal, 5(1), 591-595.

Rogachev, A. F., \& Shokhnekh, A. V. (2015). Genesis of mathematical models of econophysics as a path to food security. Audit and financial analysis, 1(1), 410-413.

Rogachev, A. F., Skiter, N. N., Shokhnekh, A. V., \& Glinskaya, O. S. (2014). Economic \& mathematical modeling of tax mechanisms of regional ecological security. Audit and financial analysis, 14(6), $140-147$.

\section{Copyrights}

Copyright for this article is retained by the author(s), with first publication rights granted to the journal.

This is an open-access article distributed under the terms and conditions of the Creative Commons Attribution license (http://creativecommons.org/licenses/by/3.0/). 